\section{A passion for walking}

\author{
John Launer
}

I have just finished walking a route across the UK from east to west- specifically from Margate in Kent to the north-west tip of Wales. At around 620 miles (1000 $\mathrm{km}$ ) it is half the length of the more famous walk from Land's End to John O'Groats and I completed it in a somewhat random fashion: my original plan had been to walk the Offa's Dyke Path along the border between England and Wales (see figure 1), but once I finished this I could not resist adding other walks including the Thames Path until I completed the whole route. Anyone with a passion for walking will understand. It has still given me a special sense of pride to be able to point to a map of my country and to say I have travelled every step across it on foot.

Long-distance walks fundamentally alter your relationship with your native geography. Every kilometre brings an unexpected discovery: who would ever guess that the river Thames, for instance, flows underneath somebody's house in Wiltshire? (see figure 2). The gradations of landscape, vegetation, history and architecture-all of which whizz by indistinguishably when passing in a car or train-become intimately familiar. Walking also tests your ingenuity, especially with regard to circumnavigating fields full of frisky bullocks, or farms guarded by overzealous dogs, not to mention finding transport back to a railway station when rural bus services in some places have become close to extinct. But none of these rewards or challenges can fully explain why one walks, or goes on walking, or seeks yet another walk to complete. For such explanations, one must look elsewhere, and especially to writing by walkers.

By a rather wonderful coincidence, one outstanding book about walking was published on almost on the same day I completed my own walk. It is called 'Walking: one step at a time', by the Norwegian explorer and writer Erling Kagge. The author's accomplishments make my own seem somewhat feeble: he has walked to the South Pole, and also to the North Pole by himself, and has climbed Everest. He is rather better placed than most people to provide some good answers to the question: 'why walk?'

Correspondence to Dr John Launer, Postgraduate Medical Journal, London WC1B 5DN, UK; johnlauner@aol.com

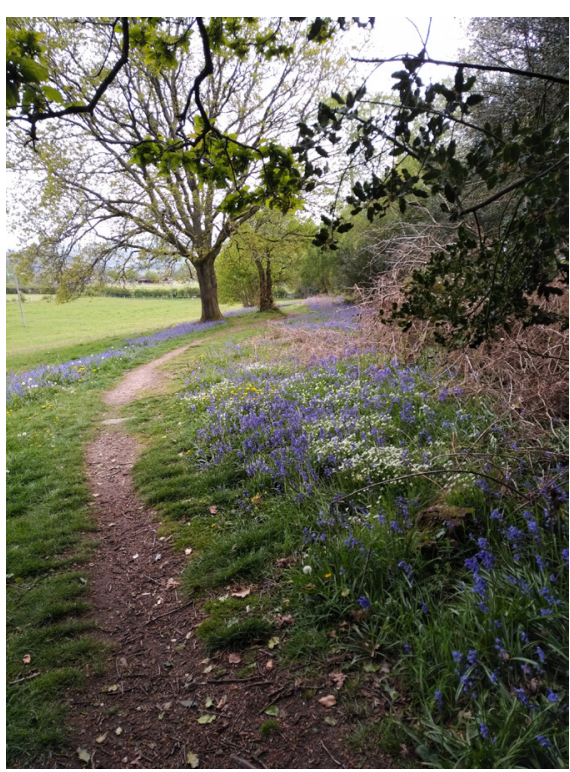

Figure 1 Offa's Dyke Path near Monmouth

\section{EFFORT AND JOY}

Kagge offers a gentle, purposefully meandering but erudite meditation on walking. Indeed, he tries to recreate the experience of walking itself. His book draws you in slowly as if to overcome the stiffness of early morning, but then gradually opens up wider and wider landscapes of thought as your mind becomes accustomed to the exercise. He also hints, brilliantly, at the aspects of walking that are almost beyond

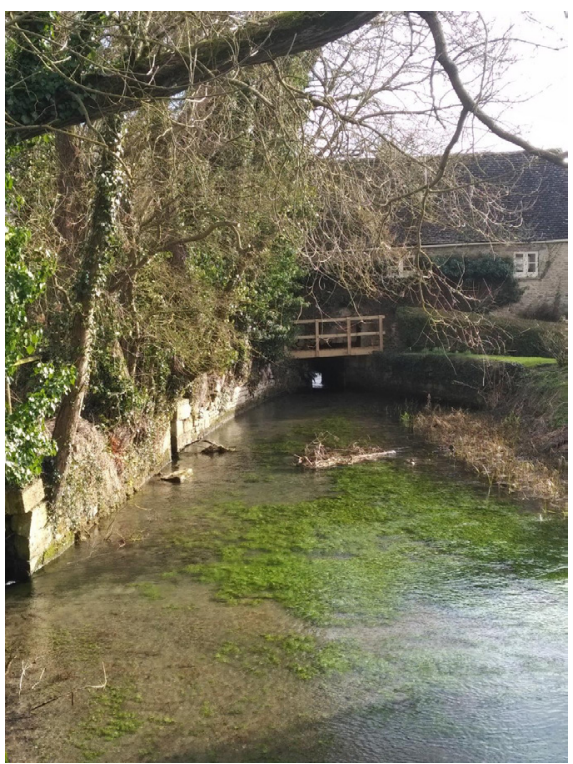

Figure 2 River Thames in Wiltshire words. Among these are its sheer uselessness, by comparison with so much else that we have to do or, more accurately, feel we ought to do. Kagge writes:

No-one has to climb Everest, and there's hardly anything else we have to do either. There are so many things we should do or could do but rarely something we have to. If you go for a long walk, you'll be fine; if you stay at home you'll be fine as well. But when something is too easily obtained, it rapidly loses its pleasure.

Although walking may sometimes arise from more mundane motivations like a desire to become fitter or to see remote places, its true essence, according to Kagge, resides in the effort for its own joyous sake.

In the course of his contemplation on walking, Kagge cites many great writers and thinkers who have themselves been devoted walkers. These include Wordsworth, Kierkegaard and Darwin. The absence of female writers about walking is curious. Possibly for most of history and in most places it was too risky for women to take long walks unaccompanied by men-although Kagge might have mentioned that Wordsworth's constant companion on his excursions was his sister Dorothy, and that some female explorers like Gertrude Bell, although accompanied by servants and pack animals, did go off on solitary walks during their expeditions.

Two writers figure significantly in Kagge's thinking. One is the Swiss author Robert Walser, whose novella 'The Walk' eerily captures the shifting inner cloudscape of thoughts, imaginary conversations, memories, fantasies and real-life encounters that accompany every walker. Another is the American philosopher and naturalist Henry David Thoreau, whose book 'Walking'? has become a classic manifesto for the habit, and who wrote:

I think I cannot preserve my health and spirits, unless I spend four hours at leastand it is commonly more than that-sauntering through the woods and over the hills and fields, absolutely free from all worldly engagements.

\section{WALKING AND CREATIVITY}

All these writers, along with many others, share an intuition that walking and writing are in some ways complementary. Walking generates ideas that can then be written about, while writing itself re-enacts the experience of exploration and discovery. (For my own part, I can disclose that I have scarcely ever written an article or chapter that was not at least partly crafted 
in my own mind while walking, and I have probably never gone for an extended walk without an idea entering into my head that I wanted to commit to paper.)

The link between walking and health is well known. Apart from the obvious benefits to musculoskeletal fitness, regular walking and other forms of moderate physical activity are associated with primary prevention of coronary heart disease and stroke, as well as type 2 diabetes. ${ }^{4-6}$ Research also confirms a clear link with creativity. The most commonly quoted paper in this respect is by Marrily Oppezzo and Daniel L Schwartz from Stanford University, entitled 'Give your ideas some legs: the positive effect of walking on creative thinking., ${ }^{7}$ Their article reports on four separate experiments involving exercise followed by standard psychological tests of both creative and convergent thinking. The exercise was of two kinds: indoor on a treadmill, and walking outside (with comparisons also being made with indoor sitting and being wheeled outdoors in a wheelchair). All four experiments showed consistent results, namely that walking substantially increases creativity, especially if it takes place outdoors. In three of the experiments, participants were more creative after walking than sitting in $81 \%, 88 \%$ and $100 \%$, respectively. In the fourth study, $100 \%$ of those who walked generated more novel ideas compared with $50 \%$ who were seated outside.

The authors conclude with the following argument:

Walking is an easy-to-implement strategy to increase appropriate novel idea generation. When there is a premium on generating new ideas in the workday, it should be beneficial to incorporate walks. In addition to providing performance benefits, it would address concerns regarding the physiological effects of inactivity. While schools are cutting back on physical education in favour of seated academics, the neglect of the body in favour of the mind ignores their tight interdependence.

This will chime with the experience of every walker, and of any doctors who have seen their patients' mental well-being, and their whole lives, improved by regular walks.

Funding The authors have not declared a specific grant for this research from any funding agency in the public, commercial or not-for-profit sectors.

Competing interests None declared.

Patient consent for publication Not required.
Provenance and peer review Not commissioned; internally peer reviewed.

(c) Author(s) (or their employer(s)) 2019. No commercial re-use. See rights and permissions. Published by BMJ.

Check for updates

To cite Launer J. Postgrad Med J 2019;95:353-354.

Accepted 22 May 2019

Published Online First 22 June 2019

Postgrad Med J 2019;95:353-354.

doi:10.1136/postgradmedj-2019-136798

\section{REFERENCES}

1 Kagge E. Walking: one step at a time. London: Penguin Viking, 2019.

2 Walser R. The walk, and other stories (translated by Middleton ( and others). 1992. London: Serpent's Tail, 1917.

3 Thoreau HD. Walking. 2017. Thomaston, ME: Tilbury House, 1862.

4 Lee I-M, Buchner DM. The importance of walking to public health. Med Sci Sports Exerc 2008;40(7 Suppl):S512-S518.

5 Vogel T, Brechat P-H, Leprêtre P-M, et al. Health benefits of physical activity in older patients: a review. Int I Clin Pract 2009;63:303-20.

6 Hanson S, Jones A. Is there evidence that walking groups have health benefits? A systematic review and meta-analysis. Br J Sports Med 2015:49:710-5.

7 Oppezzo M, Schwartz DL. Give your ideas some legs: The positive effect of walking on creative thinking. J Exp Psychol Learn Mem Cogn 2014;40:1142-52. 